\title{
Tree growth, cambial phenology, and wood anatomy of limber pine at a Great Basin (USA) mountain observatory
}

\author{
Emanuele Ziaco $^{1} \cdot$ Franco Biondi $^{1}$
}

Received: 17 August 2015/Accepted: 4 March 2016/Published online: 23 March 2016

(C) Springer-Verlag Berlin Heidelberg 2016

\begin{abstract}
Key message Anatomical features of Pinus flexilis under warmer and drier conditions along an altitudinal transect revealed a shorter growing season and shifts in the timing of wood formation.

Abstract Future climate change driven by greenhouse warming is expected to increase both frequency and severity of drought events and heat waves. Possible consequences for forest ecosystems include changes in foundation species and extended die-off phenomena. We investigated tree growth under the set of biotic and abiotic conditions, and their interactions, that are expected in a drier and warmer world using mountain observatories designed to capture elevation gradients in the Great Basin of North America. Stem cambial activity, wood anatomy, and radial growth of limber pine (Pinus flexilis) were examined at two different elevations using automated dendrometers and repeated histological microcores in 2013-2014. Mean annual temperature was $3.7^{\circ}$ cooler at the higher site, which received $170 \mathrm{~mm}_{\text {year }}{ }^{-1}$ of precipitation more than the lower site. Mean air temperature thresholds for xylogenesis computed using logistic regression were 7.7 and $12.0^{\circ} \mathrm{C}$ at the higher and lower site, respectively. No differences in the onset date of cambial activity were found under such naturally contrasted conditions, with the global change analog provided by the lower site. Growing season was shortened by increasing drought stress at the lower site, thereby reducing
\end{abstract}

Communicated by H. Gärtner.

Franco Biondi

fbiondi@unr.edu

1 DendroLab, University of Nevada, Reno, NV 89557, USA xylem production. Stem expansion was only detectable by automated dendrometers at the higher site. Using elevation to simulate climatic changes and their realized ecosystem feedbacks, it was possible to express tree responses in terms of xylem phenology and anatomical adaptations.

Keywords Pinus flexilis - Xylogenesis - Automated dendrometers $\cdot$ Temperature thresholds $\cdot$ NevCAN . Ecoclimatology · Tree rings · Vegetation shifts

\section{Introduction}

Future climate change driven by greenhouse warming is expected to increase both frequency and severity of drought episodes (e.g., Cook et al. 2014, 2015), with drastic changes in the composition and distribution of plant species. Possible scenarios for forest ecosystems include changes in species composition, including the disappearance of multiple taxa (Thomas et al. 2004), some of them key or "foundation" species (Ellison et al. 2005), upward shifting of ecosystems (Parmesan and Yohe 2003), and extended die-off phenomena (Anderegg et al. 2013). Plant demography studies based on permanent plots (Gustafson and Sturtevant 2013), tree rings (Takahashi and Okuhara 2013), and palaeoecological data (Tinner et al. 2013) have been used to predict the future distribution of species and ecosystems, but some questions still remain. For instance, the two phylogenetically similar pinyon species Pinus edulis Engelm. and Pinus monophylla Torr.\&Frém., which occupy large adjacent areas of the western US, have shown divergent dynamics during recent drought episodes, with $P$. edulis dying over large areas of the Intermountain West (Breshears et al. 2005) and P. monophylla expanding in the Great Basin (Biondi and Bradley 2013). 
Direct measurements of the macrosystem-level interaction between climate and forests can be obtained using detailed analysis of tree growth along orographic gradients (Rossi et al. 2015; Ziaco et al. 2014a). Such natural experiments help constraint simulation model results, which may not fully capture the complexity of interactions between biotic and abiotic components in determining the fate of forest landscapes as a consequence of changing climatic conditions (Worth et al. 2014). In western North America, strong elevation gradients in climate and vegetation are associated with the presence of climate-sensitive species, such as the iconic bristlecone pine (Pinus longaeva D. K. Bailey), which has been studied by dendrochronologists for decades (LaMarche 1969; LaMarche and Mooney 1972). Climatic drivers of tree-ring features, when determined using multivariate methods, are still a subject of investigation (e.g., Salzer et al. 2014), especially because statistical tools can be hampered by temporal nonstationarity, also known as the "divergence problem" (D'Arrigo et al. 2008).

Among potential climate effects on forest ecosystems, shifting plant phenology has received worldwide attention (Cleland et al. 2007). Of particular interest is the impact that anticipated or delayed tree growth might have on biogeochemical cycles (Xia et al. 2015) and species distribution (Chuine and Beaubien 2001). The effects of climate change on tree phenology have been investigated mostly in temperate and boreal ecosystems, for which an extension of the growing season is usually expected as a consequence of warming, because of earlier onset in the spring (Menzel and Fabian 1999) or delayed cessation in autumn (Rossi et al. 2011). In arid and semi-arid regions, including the southwest USA (Perry et al. 2012), there are difficulties in predicting the balance between increased evapotranspiration, changes in water-use efficiency, and photosynthesis (Le Houérou 1996). Since phenological responses to climate depend on local conditions (Nord and Lynch 2009), a wide range of responses may be expected (Cleland et al. 2007), and in situ observations are crucial to improve the predictive quality of phenological models (Richardson et al. 2012).

Cambial phenology (e.g., onset/offset of wood formation) and xylem anatomical properties can serve as useful indicators of plant short-term adaptations to mutating external conditions (Steppe et al. 2015). Internal processes like cellular division and differentiation integrate information about plant physiological responses to climatic conditions (Deslauriers and Morin 2005) and resource availability (Vieira et al. 2015). Wood tracheids, while providing conduit for water and nutrients, depend on mechanical and physiological trade-offs between structural development and resistance to drought (Sperry et al. 2006). Variability of wood anatomical parameters can then be used for retrospective studies of past hydraulic adjustments to water availability (Bryukhanova and Fonti 2013). The improvement of digital image analysis techniques has allowed climate-growth studies at the cellular level through the observation and measurement of anatomical features (Vaganov et al. 2006). Cellular dimensions, for instance, can be directly linked to the hydration status of the tree at the time of cell formation (DeSoto et al. 2011; Olano et al. 2012) as variations of lumen area usually correspond to changing levels of water conductivity (McCulloh et al. 2010). Physiological processes that determine intra-annual density fluctuations (IADFs) are also closely linked with climate variability, especially in relatively dry environments (Campelo et al. 2013; de Luis et al. 2011; Rozas et al. 2011). Overall, intra-annual dynamics of tree-ring formation (Oberhuber et al. 2014) and anatomical variables are increasingly being considered in dendroclimatic reconstruction to highlight climategrowth relationships on sub-monthly time scales (Liang et al. 2013; Panyushkina et al. 2003; Szymczak et al. 2014).

Limber pine (Pinus flexilis James), a five-needle species found in western North America over wide geographical and elevation ranges (Rundel and Yoder 1998), was used in this study to evaluate tree growth under contrasting conditions: cool and wet vs. warm and dry. The low-elevation mountain site was considered as a natural analog to simulate future changes under greenhouse forcing scenarios (Cook et al. 2014). Climatic influence on tree growth were tested using cellular and stem phenology measured at two monitoring stations in a Great Basin mountain observatory (Mensing et al. 2013), where temperature and precipitation change linearly with elevation. Our main research questions were (a) how is climate reflected in the phenology of xylem production? and (b) what modifications are found in anatomical traits of coniferous wood under warmer and drier conditions? Orographic differences provided us with a natural experiment to simulate climatic changes and their realized ecosystem feedbacks. By quantifying the start, duration, and end of the growing season, we aimed at investigating morpho-physiological adaptations to climate in wood anatomy.

\section{Materials and methods}

\section{Study sites}

Trees were sampled at the Nevada Climate-ecohydrological Assessment Network (NevCAN), which consists of two valley-to-mountain transects established between 2010 and 2013, where each station is equipped with a set of sensors mounted on a $10-\mathrm{m}$ tall tower, including standard meteorological instruments and a remotely controlled web 
camera. Soil moisture probes and tree sensors, such as automated point dendrometers, are located within the tower footprint. Soil water content (\% volume for the top $30 \mathrm{~cm}$ of the soil) is measured near each instrumented tree. Two NevCAN sites located on the western side of the Snake Range, and separated by a linear distance of $\sim 2.6 \mathrm{~km}$ and an elevation of $\sim 550 \mathrm{~m}$, were sampled for this study (Fig. 1). Daily summaries of average, minimum, and maximum air temperature $\left({ }^{\circ} \mathrm{C}\right)$, total precipitation $(\mathrm{mm})$, and solar radiation $\left(\mathrm{W} \mathrm{m}^{-2}\right)$ are publicly available from the Western Regional Climate Center website (http://www. wrcc.dri.edu/GBtransect/).

The Montane site $\left(38^{\circ} 53^{\prime} 24^{\prime \prime} \mathrm{N}, 114^{\circ} 19^{\prime} 53^{\prime \prime} \mathrm{W}, 2810 \mathrm{~m}\right)$ had mean annual temperature of $4.9^{\circ} \mathrm{C}$ and mean total annual precipitation of $426 \mathrm{~mm}$ during 2011-2014. Forest cover is composed by a mixture of limber pine, Douglas fir (Pseudotsuga menziesii (Mirb.) Franco), and white fir (Abies concolor Lindl. ex Hildebr.). Mountain mahogany (Cercocarpus ledifolius Nutt.) and greenleaf manzanita (Arctostaphylos patula Greene) form the shrub layer. The Subalpine site $\left(38^{\circ} 54^{\prime} 22^{\prime \prime} \mathrm{N}, 114^{\circ} 18^{\prime} 32^{\prime \prime} \mathrm{W}, 3355 \mathrm{~m}\right)$, which is located near treeline, had mean annual temperature of $1.2{ }^{\circ} \mathrm{C}$ and total annual precipitation of $600 \mathrm{~mm}$ in 2011-2014. Dominant species are bristlecone pine (Pinus longaeva D. K. Bailey), limber pine, and Engelmann spruce (Picea engelmannii Parry ex Engelm.), while the shrub layer is almost absent. Geological parent material is composed of dolomite and limestone, and soil is classified as loamy-skeletal carbonatic Lithic Cryorthents at the Subalpine site and carbonatic Xeric Calcicryolls at the Montane one (Johnson et al. 2014).

\section{Dendrometer records and microcore collection}

A total of 11 limber pines ( 5 at the Montane site and 6 at the Subalpine site) were sampled for histological analyses; 9 of those trees ( 3 at the Montane site; 6 at the Subalpine site) were also equipped with automated point dendrometers. Selected trees had comparable diameter at breast height (DBH, measured at about $1.3 \mathrm{~m}$ from the ground) and height to minimize the effect of tree size on ring width and anatomical features (Anfodillo et al. 2012; Carrer et al. 2015). Limber pine stem ages varied between about 50 and 100 years at both sites. Dendrometers were installed on the stem between 0.3 and $1.3 \mathrm{~m}$ from the ground, depending on the presence of branches, and some outer bark was shaved off to minimize the effect of bark swelling and shrinking. Point dendrometers measure the horizontal linear displacement of a sensing rod using a differential transformer to turn stem changes into an electrical signal with a

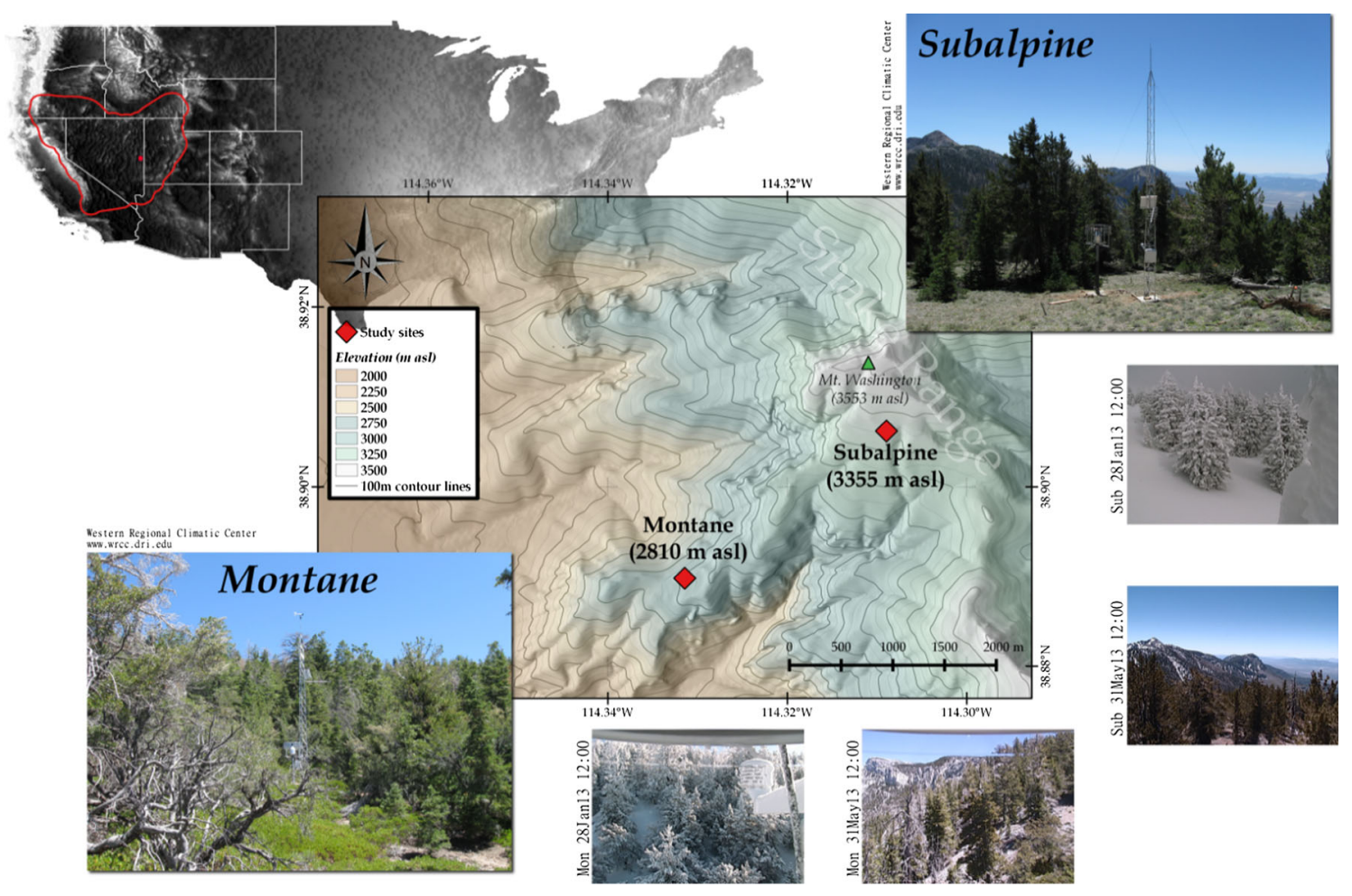

Fig. 1 Geographic location of the study sites within the US Great Basin (red outline). Webcam images of the NevCAN study areas $($ Mon $=$ Montane; Sub $=$ Subalpine $)$ were remotely captured at noon on 28 January 2013 and 31 May 2013 to illustrate the greater winter snowfall at the higher site (color figure online) 
resolution of $4 \mu \mathrm{m}$ over a range of $15,000 \mu \mathrm{m}$ (Biondi and Hartsough 2010). Stem size measurements at half-hourly intervals from October 2012 to September 2014 were smoothed to highlight the diel cycle of contraction and expansion using task-specific software (Deslauriers et al. 2011). Hourly and daily averages were combined in a sitewide composite, to enhance signal-to-noise ratio for the whole stand. Three time series were computed from dendrometer records: (1) anomalies (deviations from the longterm mean); (2) daily stem increments (obtained by subtracting the previous day maximum size from the current day maximum size); (3) cumulative stem increments (obtained by adding the daily stem increments). Cumulative stem increments were summarized at 7-day intervals to highlight radial size variation.

During 2013-2014, 286 microcores (1-2-cm long, about $1 \mathrm{~mm}$ in diameter) were extracted between June and September using either a surgical bone marrow needle or a Trephor (Rossi et al. 2006a). Usually a microcore included the developing ring and 5-15 previous tree rings. Wood microcores were collected at breast height following a spiral pattern. Coring points were separated by at least $5 \mathrm{~cm}$ in linear distance to avoid resin ducts formed after prior sampling (Dufour and Morin 2013). Given the remoteness and difficult access of the study area (Fig. 1), microcores were obtained at biweekly frequency. Immediately after extraction, microcores were stored in a $50 \%$ ethanol solution to prevent tissue deterioration, and kept refrigerated during transport to the laboratory.

\section{Xylogenesis analysis}

At the DendroLab, wood microcores were processed according to published methods (Lupi et al. 2014). First, samples were dehydrated with ethanol and Protocol SAFECLEAR II (a non-toxic substitute for xylene), and then embedded in paraffin blocks. Several transversal sections, 7-10 $\mu \mathrm{m}$ thick, were cut with a rotary microtome, and then mounted on microscope slides. Paraffin was removed from the slides with successive baths in SAFECLEAR II and pure ethanol, and sections were stained with cresyl violet acetate $(0.10 \%$ aqueous solution). Within 10-25 min from staining, sections were analyzed under a Nikon Eclipse Ci-L compound microscope with 200-400× magnification using visible (Fig. 2) and polarized light to differentiate the developing xylem cells. Cambial $[\mathrm{C}]$ and enlarging [E] cells were characterized by thin primary walls, appearing as a black belt under polarized light (Gričar et al. 2006). Cells undergoing active deposition of the secondary wall, or wall thickening cells [W], appeared purple under polarized light, while mature cells $[\mathrm{M}]$ were blue. Cells in each maturation phase (i.e., $n_{\mathrm{e}}, n_{\mathrm{w}}, n_{\mathrm{m}}$ ) were counted along three radial files (Deslauriers and Morin

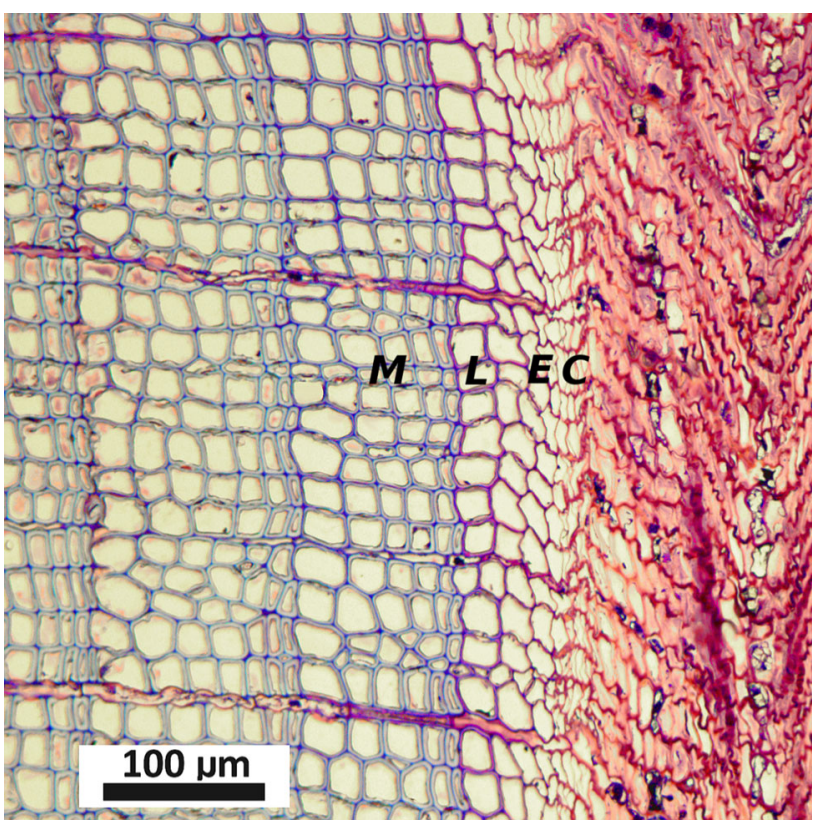

Fig. 2 Microscopic section at $100 \times$ magnification showing the annual ring being formed in late June 2013 at the Montane site. Note the reduced amount of latewood, which usually consists of 1-2 cells. $C$ cambial cells, $E$ enlarging cells, $L$ wall thickening cells, $M$ mature cells in the previous annual ring

2005). To account for the natural variability of ring width among samples collected at different points along the stem circumference, and to reduce noise in the data, cell counts were standardized by the total number of cells in the previous three rings (Rossi et al. 2003). Standardized cell counts were then averaged by tree and by site.

The timing of wood formation can be modeled by interpolating cellular counts with various mathematical functions (Kahm et al. 2010). To analyze cell production rates, and define the onset and offset of xylem formation, the cumulative sums of total cells $\left(n_{\text {ewm }}=n_{\mathrm{e}}+n_{\mathrm{w}}+n_{\mathrm{m}}\right)$, wall thickening and mature cells $\left(n_{\mathrm{wm}}=n_{\mathrm{w}}+n_{\mathrm{m}}\right)$, and mature cells only $\left(n_{\mathrm{m}}\right)$ were fitted with a Gompertz growth model using non-linear regression (Lupi et al. 2010; Rossi et al. 2003). The Gompertz function is defined as:

$y=A \exp \left(-\mathrm{e}^{\beta-\kappa t}\right)$

where $y$ is the cumulative sum of cells in a given maturation stage, $A$ is the upper asymptote given by the total number of cells, $\beta$ is the axis-placement parameter, $\kappa$ is the rate of change parameter, and $t$ is the Julian day of the year (DOY). Each phenological phase started when the first complete row of cells in that particular maturation stage had appeared (e.g., when $y=1$ ). In a strict sense, xylogenesis begins with cambial division in spring, prior to the production of newly formed cells (Savidge 2001). Xylogenesis can also refer to xylem differentiation, whose onset corresponds to the appearance of the first enlarging 
tracheid (Rossi et al. 2013). Xylogenesis offset was defined by the absence of cells undergoing active wall thickening. Timing of phenological stages was determined according to established procedures (Rossi et al. 2003), with the inflection point of the Gompertz function giving the maximum growth rate (Rossi et al. 2006b).

Cell production rate $\left(n\right.$ day $\left.^{-1}\right)$ was calculated as the ratio between the increment in number of cells $\left(n_{\text {ewm }}\right)$ and the number of days between two consecutive samples. At the end of the growing season (i.e., in latewood), negative cell increments were possible when the weekly $n_{\text {ewm }}$ was lower than its previous values. Therefore, only positive cell production rates were compared to stem size changes derived from dendrometer traces. A square root transformation was applied to cell production rates to reduce heteroscedasticity (Deslauriers and Morin 2005), and then relationships with climatic variables were evaluated by means of linear correlation and regression.

Temperature thresholds for xylogenesis were computed using a logistic regression model (Deslauriers et al. 2008). Each site-wide Gompertz function was transformed into a binary variable, using " 0 " for inactive cambium (e.g., dates prior to xylogenesis onset) and " 1 " for active cambium (e.g., dates after the onset). The logistic regression model can be expressed as:

$\operatorname{Logit}\left(\pi_{x}\right)=\ln \left(\frac{\pi_{x}}{1-\pi_{x}}\right)=\beta_{0}+\beta_{1} x_{j}$

with $\pi_{x}$ being the probability of active xylogenesis at a given temperature $x$ on a given day $j$, and $\beta_{0}$ and $\beta_{1}$ representing the intercept and slope of the regression. Temperature thresholds were computed for a 0.5 probability of having xylogenesis, thus when $\operatorname{Logit}\left(\pi_{x}\right)=0$, and $x=-\beta_{0} / \beta_{1}$ (Rossi et al. 2007). Numerical analyses were performed in the $\mathrm{R}$ software environment ( $\mathrm{R}$ Core Team 2015).

\section{Anatomical measurements}

Wood anatomy was analyzed on transverse sections cut from microcores collected after the end of the growing season. Sections were stained with safranin $(0.50 \%$ aqueous solution), and permanently mounted on microscope slides using Permount ${ }^{\mathrm{TM}}$ mounting medium (Deslauriers et al. 2003). Highly contrasted black and white images were taken at $100-200 \times$ magnification with a Lumenera Infinity1 digital camera mounted on a Nikon Eclipse Ci-L microscope, and analyzed with the WinCELL software (Guay 2013). Anatomical features included lumen area (LA), cell wall thickness (WT), cell radial diameter (CD), and wall-to-cell ratio (WtC), all measured along 6-10 radial files within each ring, and then averaged by year and by site. To make wood anatomy data comparable between sites, each anatomical parameter was represented as a standardized tracheidogram (Vaganov 1990). Standardized tracheidograms were developed using the tgram $\mathrm{R}$ package (DeSoto et al. 2011) with a standardized number of 22 cells, i.e., the mean number of cells found at our study sites.

Earlywood and latewood cells were defined following the criterion used by the WinCELL software, which is equivalent to "formula 2" in Denne (1988). Anatomical parameters were then computed for the whole ring, and separately for earlywood and latewood. Normality of anatomical parameters was evaluated using a ShapiroWilk test, and homogeneity of variances was assessed using a non-parametric, bootstrapped, modified Levene test based on absolute deviations from the median ( $\mathrm{R}$ package lawstat). Because the assumption of normality was not met by all anatomical parameters, a Kruskal-Wallis test was performed to detect significant between-sites differences of anatomical parameters. Cellular counts, wood anatomical parameters, and point dendrometer records were analyzed with respect to climatic and soil variables at daily intervals for two water-years, 2013 and 2014. A "water-year" begins on October 1 of the previous calendar year and ends on September 30 of the current calendar year (Redmond and Koch 1991).

\section{Results}

Climatic parameters recorded at sub-hourly intervals during 2011-2014 (Fig. 1) show the difference between the lower site (Montane) compared to the higher one (Subalpine). Mean annual temperature is on average $3.7^{\circ}$ cooler at the higher site, whose annual precipitation is on average $170 \mathrm{~mm}$ year $^{-1}$ more than the lower site. During the 2013 and 2014 water years, precipitation at the Subalpine site exceeded that of the Montane site by $\sim 44 \%$ (Table 1), and average maximum temperature $\left(T_{\max }\right)$ was lower by $5.6{ }^{\circ} \mathrm{C}$ in both years. Spring (April-May) in 2014 was warmer and drier than in 2013, with average minimum temperature $\left(T_{\min }\right) 0.6-0.8{ }^{\circ} \mathrm{C}$ higher, and with total precipitation about $40 \%$ less in 2014 at both sites (Table 1). Precipitation regime also varied between the 2 years, so that summer (June-August) precipitation in 2014 accounted for about a quarter of the water-year precipitation (22\% at the Subalpine, and $25 \%$ at the Montane site), whereas in 2013, which was overall wetter, summer precipitation was $12 \%$ of the water-year at the Subalpine site, and $14 \%$ at the Montane one.

The Gompertz growth model well represented the patterns we found in cell counts for all maturation phases. The onset of xylem production (Table 2) occurred at the end of May (DOY 151) at the lower elevation, and a few days 
Table 1 Summary of daily climatic variables measured at the two NevCAN study sites, Montane and Subalpine

\begin{tabular}{|c|c|c|c|c|c|c|c|c|c|}
\hline \multirow[t]{2}{*}{ Water year } & \multirow[t]{2}{*}{ Months } & \multicolumn{4}{|c|}{ Subalpine } & \multicolumn{4}{|c|}{ Montane } \\
\hline & & Avg. $T$ & Avg. $T_{\max }$ & Avg. $T_{\min }$ & $P$ & Avg. $T$ & Avg. $T_{\max }$ & Avg. $T_{\min }$ & $P$ \\
\hline 2013 & October-September & 1.1 & 6.4 & -3.0 & 597 & 5.0 & 12.0 & -0.10 & 413 \\
\hline 2013 & October-May & -3.5 & 1.5 & -7.6 & 436 & -0.0 & 6.5 & -4.9 & 278 \\
\hline 2013 & April-May & -0.0 & 5.3 & -4.7 & 135 & 4.7 & 12.5 & -1.5 & 77 \\
\hline 2013 & June-August & 12.0 & 18.1 & 7.3 & 71 & 16.9 & 25.0 & 10.9 & 59 \\
\hline 2014 & October-September & 1.2 & 6.5 & -3.2 & 626 & 5.1 & 12.1 & -0.1 & 422 \\
\hline 2014 & October-May & -3.2 & 1.9 & -7.4 & 394 & 0.3 & 6.9 & -4.6 & 227 \\
\hline 2014 & April-May & 0.6 & 5.8 & -4.1 & 57 & 5.4 & 12.8 & -0.7 & 29 \\
\hline 2014 & June-August & 10.6 & 16.4 & 6.6 & 139 & 15.4 & 23.3 & 9.2 & 111 \\
\hline
\end{tabular}

$P$ total precipitation $(\mathrm{mm}), T$ air temperature $\left({ }^{\circ} \mathrm{C}\right)$

later, during the first week of June (DOY 152 in 2013 and DOY 156 in 2014), at the higher one (Fig. 3; Table 2). No differences emerged between the two water years concerning the onset of wood production, even after a fallspring period (October 2013-May 2014) considerably drier than the previous year (Table 1). In 2013, the onset of cell wall thickening was delayed about 1 week at the higher site, with cells undergoing deposition of secondary walls appearing on DOY 159 (June 8) at the Montane site, and on DOY 166 (June 15) at the Subalpine site. In 2014, cell wall thickening still began earlier at the lower elevation, but later than in 2013 at both sites (Table 2). The process of cell maturation was even more different between sites: fully formed cells appeared at the Montane site already in the third week of June in 2013 (DOY 173) and 2014 (DOY 170), while at the Subalpine site cells completing their maturation appeared more than 2 weeks later, on DOY 191 (July 10) in 2013 and on DOY 185 (July 4) in 2014 (Table 2).

Cell production reached its peak (Fig. 3) about a week after the onset of xylem differentiation (DOY 159) at the Montane site, and about 2 weeks later, in the last week of June, at the Subalpine site. At the lower elevation, the final number of cells was reached in early July, when no newly formed enlarging cells were present, while active cellular division continued until mid- to late-August at the Subalpine site (Fig. 3a, b; Table 2). Latewood formation at the Subalpine site started during the first week of September in 2013, and lasted about 14 days, while in 2014 latewood cells appeared about 2 weeks earlier, in mid-August (Fig. 3a, b), preceding the completion of cell maturation in mid-September. At the Montane site, latewood cells appeared in the second half of July, and were about a week earlier in 2014 than in 2013 (Table 2). As cells were going through the deposition of secondary wall, the formation of latewood cells at the Montane site corresponded with decreased water availability and prolonged heat stress, leading to the complete maturation of all cells (i.e., the end of xylogenesis) by mid-August (Fig. 3c, d).

The average number of tracheids per ring was usually less than ten $(8 \pm 2$ in 2013 and $9 \pm 3$ in 2014) at the lower site, three to four times less than at the higher site ( $39 \pm 14$ cells in 2013 and $31 \pm 6$ in 2014). The growing season for $P$. flexilis lasted approximately 75 days at the Montane site, while at the Subalpine site tree ring formation was completed in $89-107$ days (Table 2). The period of active cellular growth (enlargement phase), remained constant during both years, lasting 1 month at the Montane site and more than twice ( $\sim 2.6$ months) at the Subalpine site (Table 2).

Stem size, as recorded by point dendrometers, increased at the Subalpine site throughout the growing season (Fig. 3a, b). Mean 7-day stem increment was significantly positive between the end of May and the first week of June, in general agreement with xylogenesis patterns derived from cellular measurements at the Subalpine site. At the Montane site, 7-day stem increment remained close to zero throughout the entire growing season, making it impossible to define the onset of stem radial enlargement (Fig. 3c, d). Continuous radial shrinkage, totaling $0.2-0.5 \mathrm{~mm}$, was observed between the spring melting of the snowpack and the August precipitation. Cell production rates and cumulative stem increment, which were directly correlated at both sites, showed reduced growth at the warmer and drier site (Fig. 4). At the Montane site, minimum air temperature had the highest correlation with the number of new cells formed per day (Pearson's $r=-0.97, p=0.005$ ). Soil water content at the lower elevation was directly correlated with stem increment measured by the dendrometers $(r=0.97, p=0.006)$.

Daily air temperature thresholds at which tracheid formation had a 0.5 probability to occur were averaged by site (Fig. 5). The threshold for mean temperature was $4.3^{\circ}$ higher at the Montane site $\left(12.0^{\circ}\right)$ than the Subalpine one 


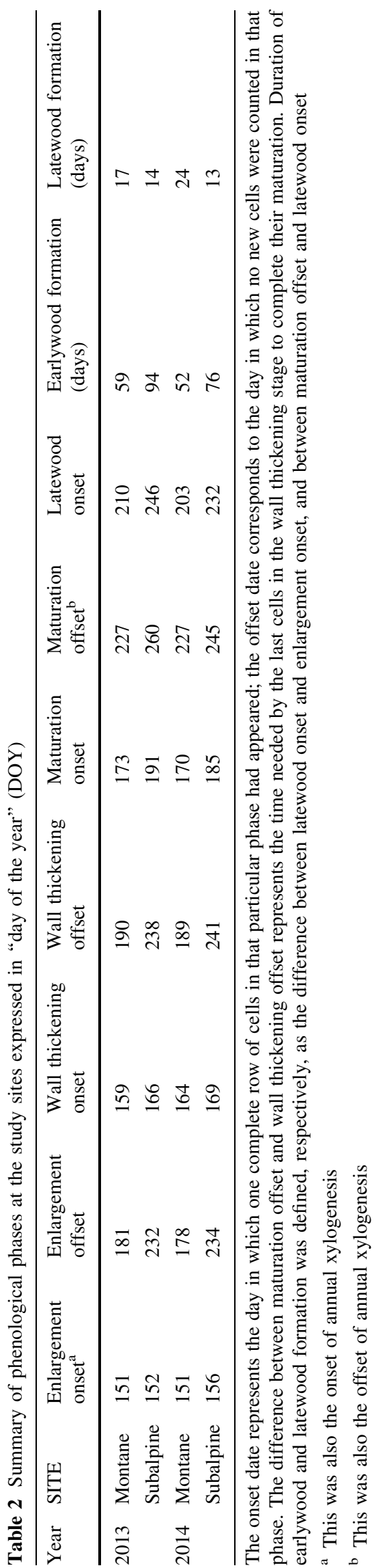

$\left(7.7^{\circ}\right)$, and the difference was larger when considering maximum temperature $\left(19.9^{\circ}\right.$ and $13.3^{\circ}$ at the Montane and Subalpine site, respectively). Thresholds for minimum temperature were less different between sites $\left(5.2^{\circ}\right.$ at the lower elevation and $2.7^{\circ}$ at the treeline), but still in the same direction with regard to climatic controls of wood production, and ultimately tree growth and ecosystem productivity.

Standardized tracheidograms (Fig. 6) highlighted the difference between elevations, as wood cells formed at the Subalpine site had tracheid size, in particular lumen area (LA) and cell diameter (CD), larger than at the Montane site (Table 3). Average area of conduit lumens in the earlywood $\left(\mathrm{LA}_{\mathrm{ew}}\right)$ was significantly different between the two sites (Table 4). Lumens of tracheids formed in June, the most active month for cell formation, were about $73 \%$ wider at the Subalpine than at the Montane site (Fig. 6a). At the interannual level, the reduced amount of spring precipitation in 2014 led to a modest contraction ( $-2 \%$, not statistically significant) of average lumen size in tracheids formed early in the season $\left(\mathrm{LA}_{\text {ew }}\right)$ at the Subalpine site (Table 3). Cell wall thickness (WT) was similar at both sites, with no differences between average wall thickness in the earlywood and latewood (Fig. 6b). Thus, given the differences in cell lumen mentioned above, tracheids had on average a wider radial diameter at the Subalpine site; $\mathrm{CD}_{\mathrm{ew}}$ was +21 and $+29 \%$ in 2013 and 2014, respectively (Fig. 6c; Table 4). Consequently, the wall-to-cell ratio (WtC) was significantly higher at the Montane site (Fig. 6d; Table 4), and the boundary between earlywood and latewood was determined by tracheid lumen. The majority $(\sim 70 \%)$ of trees at both sites had very narrow latewood bands (Fig. 2).

\section{Discussion}

The arid and semi-arid environments of the southwest US are expected to experience a drier and warmer future (Cook et al. 2015); understanding plant physiological and anatomical responses to a changing environment, therefore, helps with predicting the fate of forest ecosystems in this region. Simulating climate-ecosystem interactions can be hampered by non-linear interactions between biotic and abiotic factors, including microclimatic effects of vegetation cover on soil properties, either physical, such as soil temperature (Harte and Shaw 1995), or chemical, such as soil nutrients (Johnson et al. 2014). Temperature is indeed a primary driver of cambial activity, in particular for interrupting winter dormancy (Gruber et al. 2010; Lenz et al. 2013; Oribe and Kubo 1997; Seo et al. 2008). Cambial reactivation can even be artificially triggered by the localized heating of stem portions in the spring (Gričar et al. 2006). Sensitivity of xylogenesis to temperature 
(a) Subalpine 2013

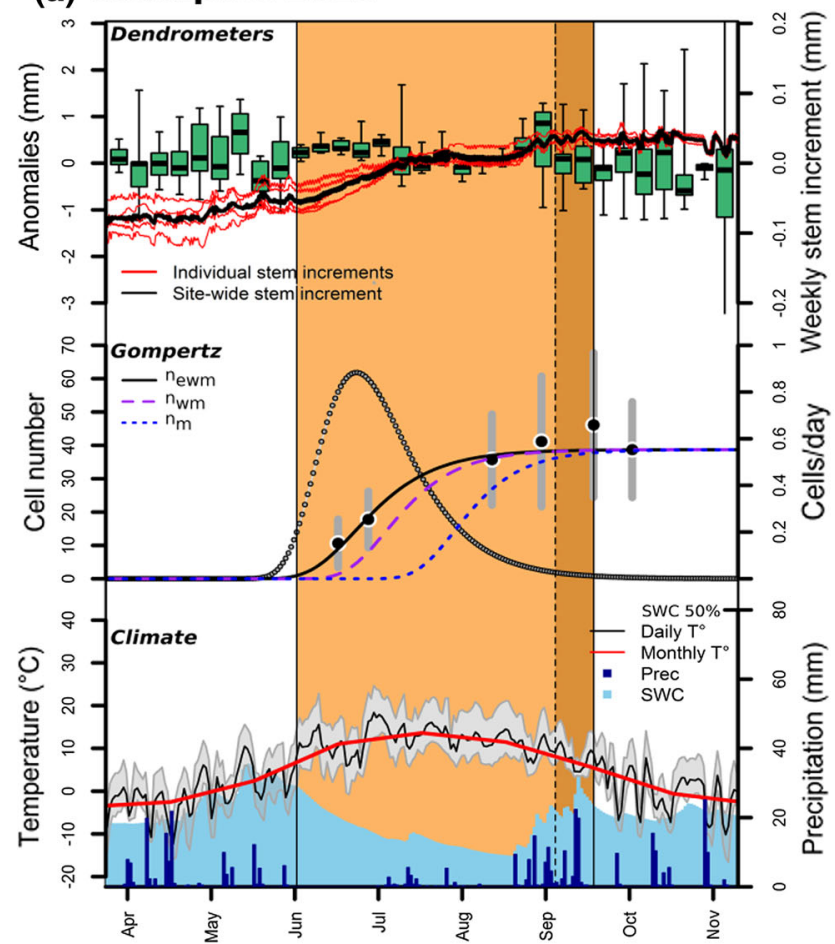

(c) Montane 2013

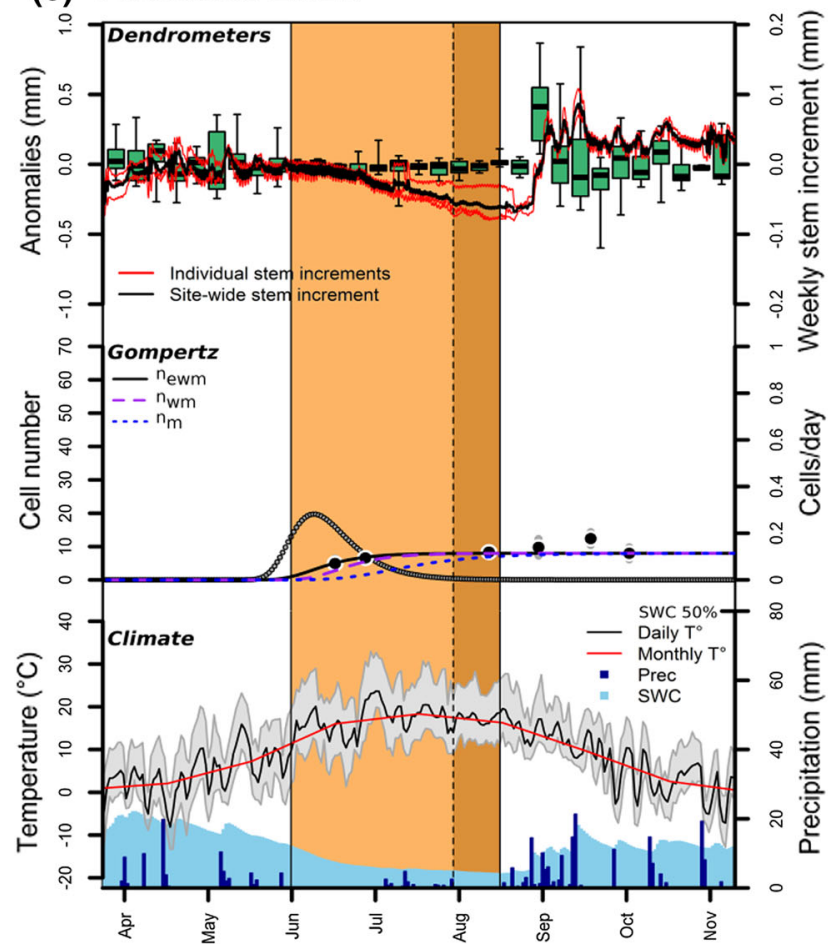

generally increases at high elevations, where trees can benefit from warmer conditions to begin cambial activity earlier in the season (Deslauriers et al. 2008). In temperate and cold climates, the temporal window of cambial activity becomes shorter with increasing altitude (Moser et al. (b) Subalpine 2014

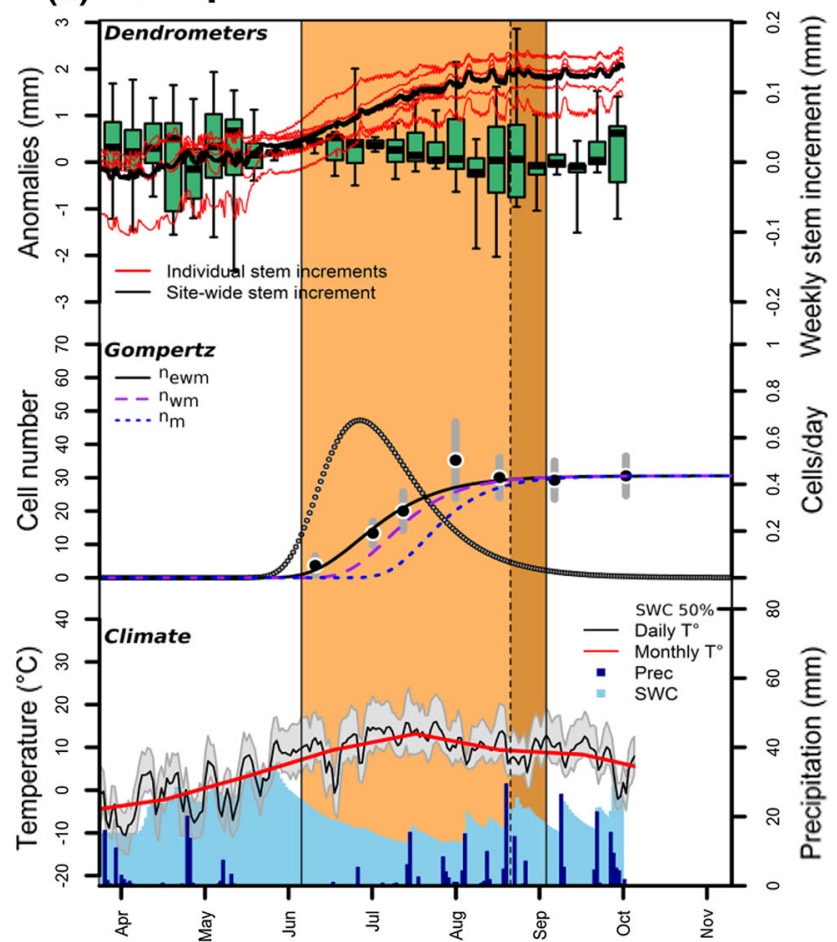

(d) Montane 2014

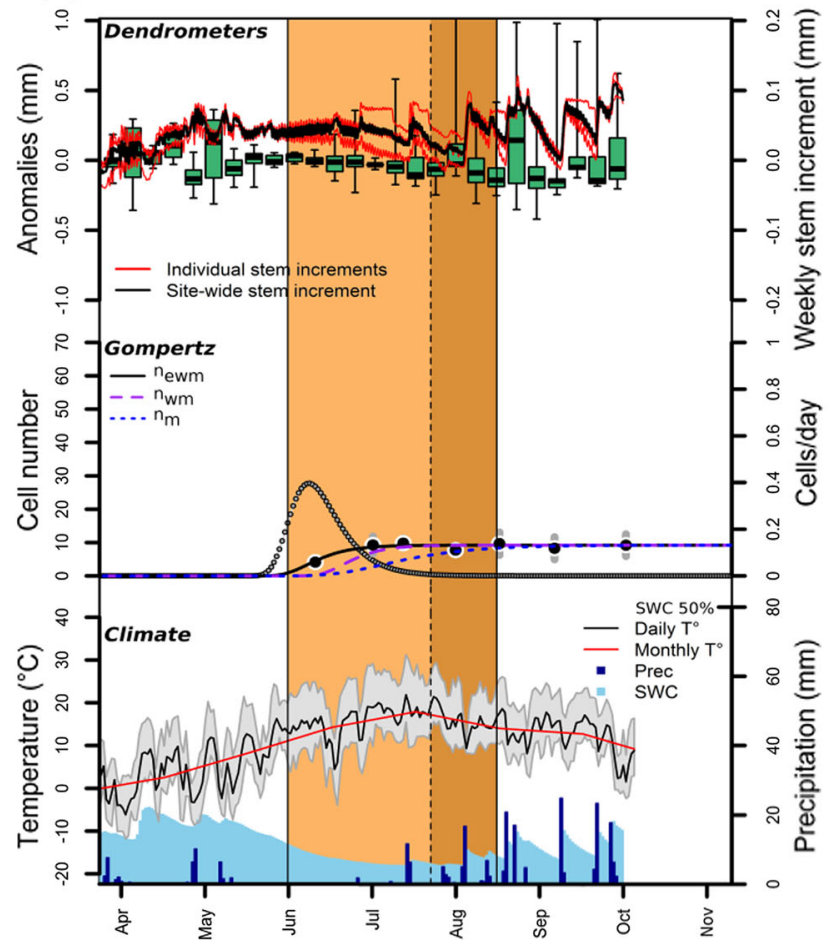

2010), in agreement with a general extension of plant phenology under milder climatic conditions (Boulouf Lugo et al. 2012). Similarly at high latitudes, i.e., in boreal forests, water availability does not limit tree growth, and cambial activity benefits from increasing temperature, 
4Fig. 3 Dendrometers records, Gompertz functions, and climate variables for years 2013-2014 at the Subalpine (a, b) and Montane (c, d) sites. Dendrometers: stem size anomalies recorded by point dendrometers (red lines), and their site composites (black thick line; scale is shown on the left y-axis). Cumulative stem increments were summarized at 7-day intervals (green boxplots; scale is shown on the right y-axis). Gompertz: biweekly measurements of total cells $\left(n_{\text {ewm }}\right) \pm$ standard deviation (black dots with gray bars) were fit with a Gompertz function (black solid line). The Gompertz functions for total wall thickening $\left(n_{\mathrm{w}}\right.$; dashed purple line) and mature cells $\left(n_{\mathrm{m}}\right.$; dotted blue line) are also shown, together with daily cell production rates (gray circles). Background brownish area represents the overall duration of xylogenesis detected using the Gompertz functions, from the appearance of the first enlarging cell to the complete maturation of the last wall thickening cell (light brown for earlywood; dark brown for latewood). Climate: mean daily temperature (black line) was plotted within the gray-shaded area defined by mean daily maximum and minimum temperature, and overlaid with mean monthly temperature (solid red line). Total daily precipitation (blue bars) was plotted within the light blue-shaded area defined by relative soil water content (SWC; measured at 0-30 cm depth) (color figure online)

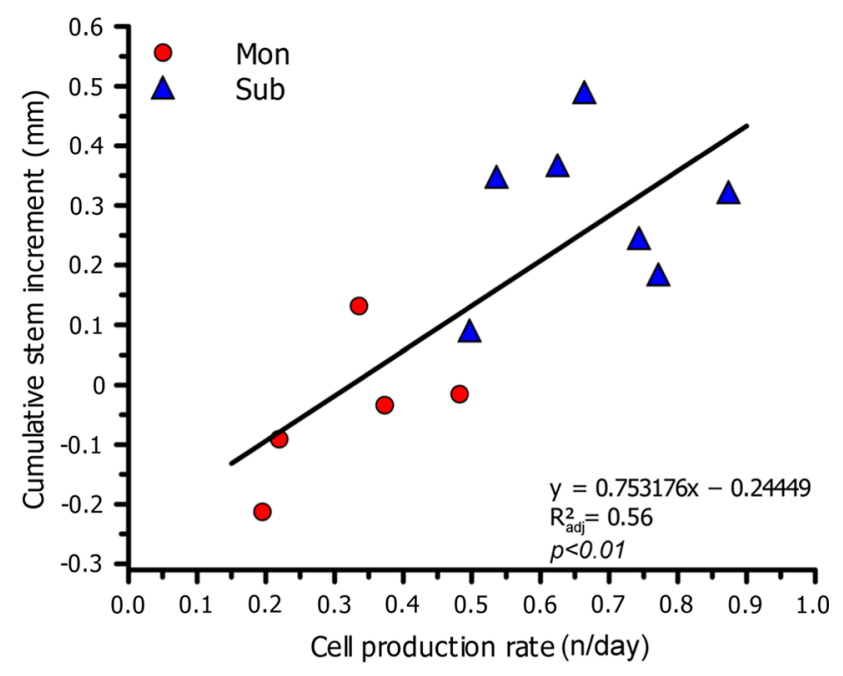

Fig. 4 Scatterplot and regression line between cell rate production and cumulative stem increment at the two study sites (Mon $=$ Montane; Sub $=$ Subalpine) during both years. Cumulative stem increment was derived from the stand composite of dendrometer traces (see Fig. 3). Cell production rate (number of cells per day) was calculated as the difference between biweekly cellular measurements using all available microcores (see Fig. 3). The number of points (5 for Montane, 7 for Subalpine), therefore, refers to the number of cell production increments during active xylogenesis

hence a longer growing season can be expected as a consequence of climate warming (Rossi et al. 2011, 2014).

Research conducted on temperature-limited environments, either at high elevations or at high latitudes, is best viewed in conjunction with studies for relatively dry environments, which are vulnerable to even moderate increases in air temperature and water stresses (Allen et al. 2010; Breshears et al. 2005). Conifers experiencing pronounced summer drought show a period of reduced

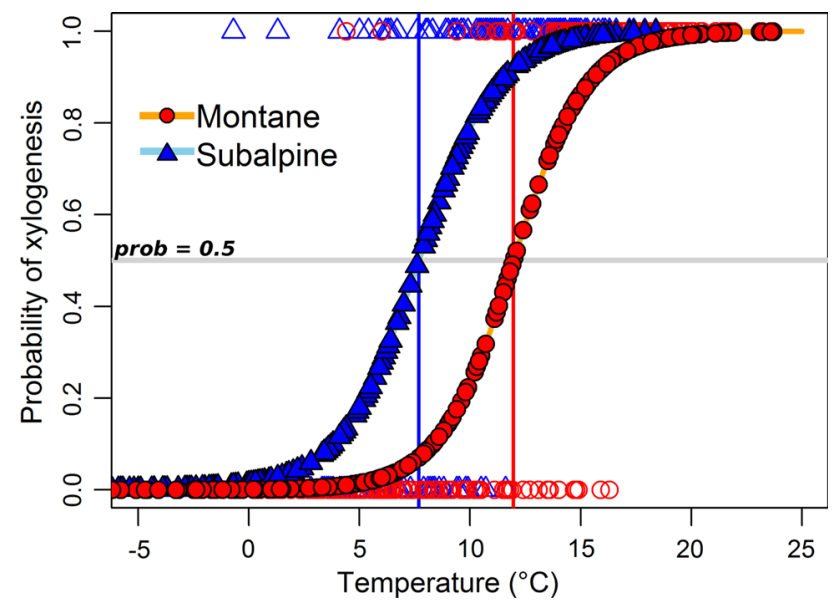

Fig. 5 Probability functions of xylogenesis associated with mean air temperature calculated using a logistic regression for the Montane (red circles) and Subalpine (blue triangles) site. Xylogenesis ( $O$ for inactive cambium, 1 for active cambium) probabilities are shown for observed (empty symbols) and model-predicted (solid symbols) values. Vertical lines represent temperature thresholds for the Subalpine (blue) and Montane (red) site (color figure online)

cambial activity during the dry season (Vieira et al. 2013, 2015), and studies conducted in the Mediterranean region have found that tree-growth cessation in Pinus pinaster Aiton was actually triggered by low water availability (Vieira et al. 2014). Our results relate closely with some of those studies, as growing season length was considerably shorter at the lower, i.e., drier and warmer, elevation.

Overall, the most significant differences were found in the timing of cambial phenophases, in particular the offset of xylogenesis, on a spatial scale (i.e., between sites) rather than a temporal one (i.e., between years). The beginning of cellular enlargement and wall thickening was essentially simultaneous across elevations, while the appearance of mature cells was delayed by more than 2 weeks at the higher site. Maximum growth rate at the Subalpine site occurred close to the summer solstice, suggesting a connection with photoperiod. To achieve the complete formation of secondary walls of newly formed tracheids before the beginning of the cold season, trees growing at treeline synchronize their growth rates with daylength (Rossi et al. 2006b), as confirmed by recent phenological observations conducted at the same study site on bristlecone pine (Ziaco et al. 2016). Analogously, temperature thresholds for xylogenesis at the Subalpine site were in agreement with temperatures that identify treeline position on a global scale (Körner and Paulsen 2004). Temperature thresholds for xylem production at lower elevations are lacking, hence our contribution ameliorates a knowledge gap, especially considering the $4.3{ }^{\circ} \mathrm{C}$ difference at the Montane site. Maximum growth rates, which occurred shortly after the beginning of tree-ring formation at the 

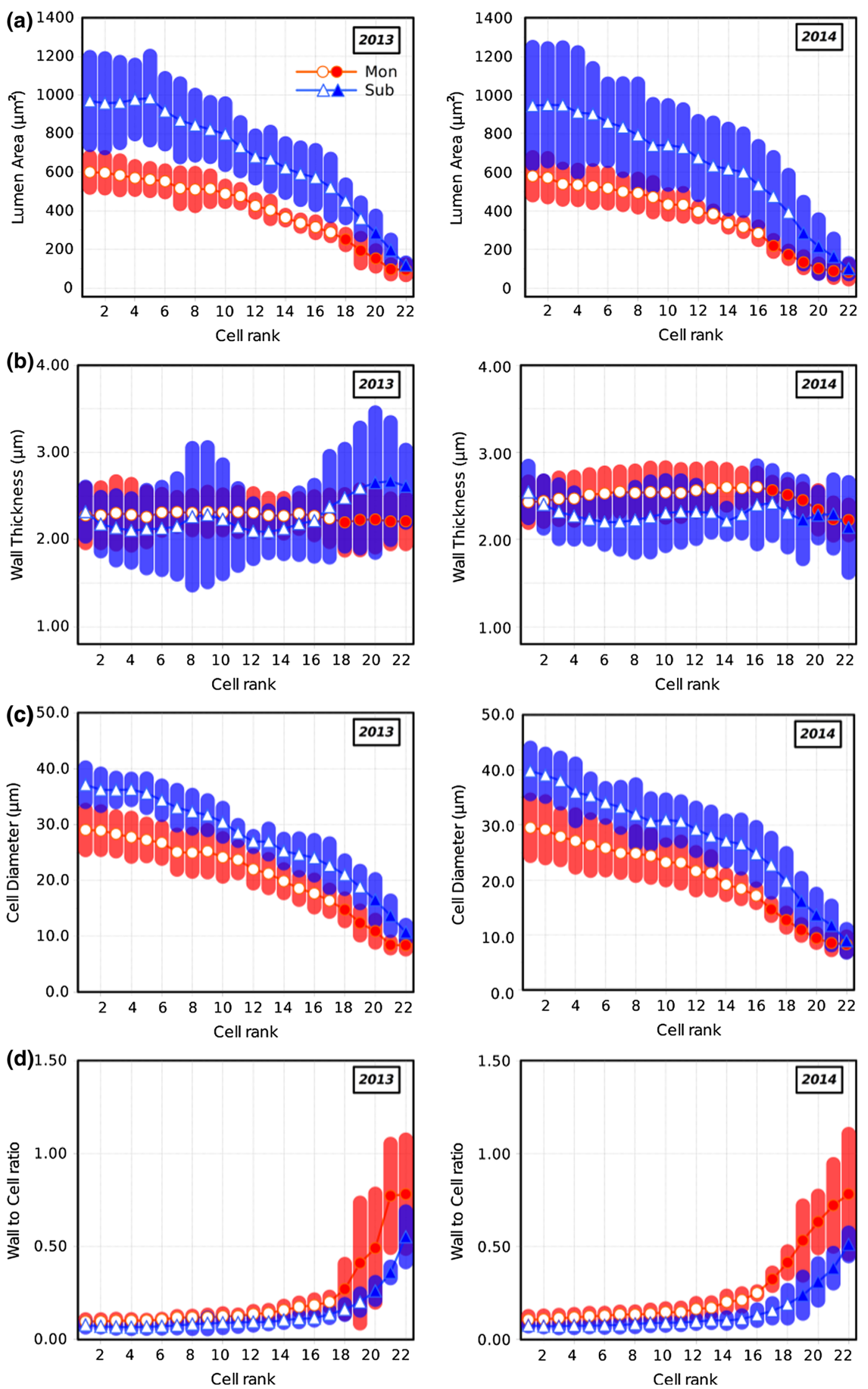
4Fig. 6 Standardized tracheidograms (number of cells $=22$ ) of a lumen area, $\mathbf{b}$ wall thickness, $\mathbf{c}$ cell diameter, and $\mathbf{d}$ wall-to-cell ratio measured in 2013 (left column) and 2014 (right column) at the Montane (Mon) and Subalpine (Sub) site. Empty symbols represent earlywood tracheids, while solid symbols identify the latewood; vertical bars represent \pm 1 standard deviation

Montane site, also indicates that trees in drier and warmer conditions rapidly exploit soil moisture made available by snowmelt before the arrival of peak summer drought.

At the Montane site, because of very low cell production rates, dendrometer records did not detect stem increases, which were instead clearly detected at the Subalpine site. Trees were unable to recover water lost through transpiration during the day, and the formation of relatively few or no cells did not compensate for stem drying, leading to undetectable radial increment at the drier and warmer site, as normally happens in Mediterranean environments (Vieira et al. 2013). As growing season length regulated wood formation, it led to reduced stem increment, a proxy for overall tree growth and ecosystem productivity, at the lower elevation. At both sites, with the arrival of late summer and fall precipitation, when the vascular cambium was already dormant, the outermost tissues (e.g., phloem and residuals of inner bark) were rehydrated, causing stem expansion without formation of new xylem (Biondi and Rossi 2015). Therefore, if considered independently of histological analysis, dendrometer records could have estimated the onset of $P$. flexilis radial growth at the Subalpine site, but not at the Montane one. Furthermore, the variability in daily stem shrinkage and expansion caused by fall precipitation would have made it nearly impossible to define the end of annual tree-ring formation.

Both wood cell formation and dendrometer records showed few significant relationships with environmental variables. In these mountain environments, precipitation is associated with cloudy skies, reduced evapotranspiration, and lower air temperature (Biondi and Rossi 2015), hence correlations with climatic variables have mostly a heuristic value, while the amount of observed growth incorporates biotic and abiotic effects on tree productivity. Nevertheless, larger tracheids found at the Subalpine site could represent an acclimation of limber pine anatomy to greater water availability (DeSoto et al. 2011; Martin-Benito et al. 2013). The cross-sectional surface (or lumen area) of water conduits directly reflects the hydration status of the plant at the moment of cell formation during the growing season, and it represents the final outcome of complex mechanical and physiological trade-offs between structural development and resistance to drought in the hydraulic architecture of the stem (Sperry et al. 2006). Water is needed to maintain cellular turgor during tracheid expansion, affecting the duration of the enlargement phase and the final tracheid size (Cuny et al. 2014). This mechanism could then lead to significant differences in cellular parameters (e.g., lumen area and cell diameter), as was found at our study sites. Such anatomical response, which suggests a plastic ability to adapt, is consistent with reports of physiological acclimation to drought in limber pine populations (Letts et al. 2009), and has been found in other Great Basin conifers (Ziaco et al. 2014a) as well as in other pine species from relatively dry regions (Vieira et al. 2014).

In the arid and semi-arid regions of the western US, dendroclimatic interactions are influenced by orography and topography (Bunn et al. 2011; Salzer et al. 2014), thus climate sensitivity can be highly dependent on local conditions. In our study, water soil content during the growing season was quickly recharged by precipitation, but presence/absence of shrubs can modify the level of competition for resources, and a more abundant shrub layer was present

Table 3 Summary of anatomical parameters (mean \pm standard error) measured at the two study sites in 2013 and 2014

\begin{tabular}{llllllllll}
\hline Year & Site & $\mathrm{LA}_{\mathrm{ew}}\left(\mu \mathrm{m}^{2}\right)$ & $\mathrm{LA}_{\mathrm{lw}}\left(\mu \mathrm{m}^{2}\right)$ & $\mathrm{WT}_{\mathrm{ew}}(\mu \mathrm{m})$ & $\mathrm{WT}_{\mathrm{lw}}(\mu \mathrm{m})$ & $\mathrm{CD}_{\mathrm{ew}}(\mu \mathrm{m})$ & $\mathrm{CD}_{\mathrm{lw}}(\mu \mathrm{m})$ & $\mathrm{WtC}_{\mathrm{ew}}$ & $\mathrm{WtC}_{\mathrm{lw}}$ \\
\hline \multirow{2}{2}{2013} & Montane & $465 \pm 22$ & $134 \pm 8$ & $2.28 \pm 0.11$ & $2.23 \pm 0.14$ & $23.4 \pm 1.4$ & $10.0 \pm 0.4$ & $0.13 \pm 0.00$ & $0.61 \pm 0.09$ \\
& Subalpine & $745 \pm 71$ & $185 \pm 25$ & $2.22 \pm 0.23$ & $2.65 \pm 0.30$ & $29.4 \pm 1.0$ & $13.1 \pm 1.4$ & $0.10 \pm 0.01$ & $0.41 \pm 0.03$ \\
\multirow{2}{*}{2014} & Montane & $466 \pm 28$ & $147 \pm 18$ & $2.53 \pm 0.12$ & $2.41 \pm 0.06$ & $24.3 \pm 1.7$ & $11.3 \pm 0.5$ & $0.15 \pm 0.01$ & $0.55 \pm 0.07$ \\
& Subalpine & $725 \pm 103$ & $159 \pm 23$ & $2.29 \pm 0.09$ & $2.35 \pm 0.18$ & $30.7 \pm 1.7$ & $11.9 \pm 0.9$ & $0.10 \pm 0.01$ & $0.40 \pm 0.02$
\end{tabular}

LA lumen area, $W T$ wall thickness, $C D$ cell diameter, $W t C$ wall-to-cell ratio; all values were calculated separately for earlywood (ew) and latewood $(l w)$

Table 4 Chi-squared statistics (bold characters for significant ones) and their $p$ values for the Kruskal-Wallis test between anatomical parameters at the Montane and Subalpine site

\begin{tabular}{llrrr}
\hline Year & Lumen area & Wall thickness & Cell diameter & Wall-to-cell ratio \\
\hline 2013 & $\mathbf{1 2 . 5 6}(\mathrm{p}<0.001)$ & $1.98(p=0.159)$ & $\mathbf{7 . 0 3}(p=0.008)$ & $\mathbf{9 . 1 6}(p=0.002)$ \\
2014 & $\mathbf{1 2 . 0 6}(\mathrm{p}<0.001)$ & $\mathbf{2 0 . 7 3}(\mathrm{p}<0.001)$ & $\mathbf{9 . 0 2}(\mathrm{p}=0.003)$ & $\mathbf{1 1 . 4 2}(\mathrm{p}<0.001)$ \\
\hline
\end{tabular}


at the lower site compared to the higher one (Ziaco et al. 2014b). Given the above-mentioned connections between climate and wood anatomical parameters, in particular lumen area and cell diameter, stand structure is unlikely to be responsible for the reduced growth rates found at the lower elevation. Vegetation changes reported when air temperature increases at high latitudes (Sturm et al. 2001) or elevations (Brandt et al. 2013) suggest that encroachment of shrub species is to be expected in those ecosystems under global warming scenarios. The resulting trends in species composition (Grabherr et al. 1994) and dominance relationships of tree communities (Kelly and Goulden 2008) would, therefore, be well represented by the currently greater shrub cover at the Montane site compared to the Subalpine one. In addition, we found no evidence of pronounced age differences between elevations; if trees at the subalpine site were older, phenology should have been even more different from the lower site, as greater stem age has been linked with shorter duration of xylogenesis and lower cell production for high-elevation conifers (Rossi et al. 2008).

Tree growth, and in particular wood formation, is a dynamic process regulated not only by environmental factors, but also by genetic mechanisms (Hertzberg et al. 2001; King et al. 2013). While the contribution of genotypic plasticity in defining the chances for a given species to withstand new climatic and environmental conditions cannot be overstated (Alfaro et al. 2014; Sthultz et al. 2009), understanding temporal patterns of tree growth in response to environmental drivers is crucial to improve the interpretation of dendroclimatic records, since environmental parameters affecting wood production may have different effects in different periods of the growing season (Rossi et al. 2006b). Trees in general hold a high degree of plasticity to respond to seasonal variations of environmental conditions, in particular water and temperature stress. The hydraulic architecture of newly formed tracheids, e.g., their size and number, can then preserve water transport and maintain hydraulic safety in dry environments (Bryukhanova and Fonti 2013) as well as in cold climates where freeze-induced embolism might occur (Pittermann and Sperry 2003). Our results indicate that phenology and wood anatomy of $P$. flexilis in the Great Basin are linked to environmental conditions during the warm season (June-August). Therefore, increased summer heat and water stress predicted under global warming scenarios would shorten the growing season by anticipating the cessation of xylogenesis, leading to reduced productivity and carbon assimilation.

In conclusion, the ability to succinctly represent tree responses in a warmer and drier world can be captured using targeted field studies along elevation gradients, which simulate climatic changes together with their realized ecosystem feedbacks. The ability to observe in situ processes at sub-hourly intervals using automated sensors is crucial to evaluate global change simulations of tree growth responses at scales most relevant for natural resource management. Our study of a foundation tree species, made possible by newly established mountain observatories, quantified how warmer and drier conditions lead to a shorter growing season and a lower amount of tree growth, which were expressed as phenological and wood anatomical adaptations.

Author contribution statement EZ performed the field work and laboratory analysis, prepared figures, and contributed to writing the manuscript. FB designed the research project, supervised field and laboratory personnel, and contributed substantially to writing the manuscript.

Acknowledgments We are grateful to Scotty Strachan for assistance with NevCAN, Greg McCurdy for helping with data retrieval, Sergio Rossi and Annie Deslauriers for advice on wood anatomy and dendrometer data evaluation. The comments of the Communicating Editor and of two anonymous Reviewers helped with improving an earlier version of the manuscript.

\section{Compliance with ethical standards}

Conflict of interest Research was supported, in part, by the US National Science Foundation under grants AGS-P2C2-1401381 and 1502379. Additional funding was provided by the College of Science of the University of Nevada, Reno, in relation to NevCAN. The views and conclusions contained in this document are those of the authors and should not be interpreted as representing the opinions or policies of the funding agencies and supporting institutions. The authors declare that they have no conflict of interest.

\section{References}

Alfaro RI, Fady B, Vendramin GG, Dawson IK, Fleming RA, SaenzRomero C, Lindig-Cisneros RA, Murdock T, Vinceti B, Navarro CM, Skroppa T, Baldinelli G, El-Kassaby YA, Loo J (2014) The role of forest genetic resources in responding to biotic and abiotic factors in the context of anthropogenic climate change. For Ecol Manage 333:76-87

Allen CD, Macalady AK, Chenchouni H, Bachelet D, McDowell NG, Vennetier M, Kitzberger T, Rigling A, Breshears DD, Hogg EH, Gonzalez P, Fensham R, Zhang Z, Castro J, Demidova N, Lim J-H, Allard G, Running SW, Semerci A, Cobb NS (2010) A global overview of drought and heat-induced tree mortality reveals emerging climate change risks for forests. For Ecol Manag 259:660-684

Anderegg WRL, Kane JM, Anderegg LDL (2013) Consequences of widespread tree mortality triggered by drought and temperature stress. Nat Clim Change 3:30-36

Anfodillo T, Deslauriers A, Menardi R, Tedoldi L, Petit G, Rossi S (2012) Widening of xylem conduits in a conifer tree depends on the longer time of cell expansion downwards along the stem. J Exp Bot 63:837-845

Biondi F, Bradley ML (2013) Long-term survivorship of singleneedle pinyon (Pinus monophylla) in mixed-conifer ecosystems of the Great Basin. USA. Ecosphere 4:art120 (19 pages) 
Biondi F, Hartsough PC (2010) Using automated point dendrometers to analyze tropical treeline stem growth at Nevado de Colima, Mexico. Sensors 10:5827-5844

Biondi F, Rossi S (2015) Plant-water relationships in the Great Basin Desert of North America derived from Pinus monophylla hourly dendrometer records. Int J Biometeorol 59:939-953

Boulouf Lugo J, Deslauriers A, Rossi S (2012) Duration of xylogenesis in black spruce lengthened between 1950 and 2010. Ann Bot 110:1099-1108

Brandt JS, Haynes MA, Kuemmerle T, Waller DM, Radeloff VC (2013) Regime shift on the roof of the world: Alpine meadows converting to shrublands in the southern Himalayas. Biol Conserv 158:116-127

Breshears DD, Cobb NS, Rich PM, Price KP, Allen CD, Balice RG, Romme WH, Kastens JH, Floyd ML, Belnap J, Anderson JJ, Myers OB, Meyer CW (2005) Regional vegetation die-off in response to global-change-type drought. Proc Nat Acad Sci USA 102:15144-15148

Bryukhanova M, Fonti P (2013) Xylem plasticity allows rapid hydraulic adjustment to annual climatic variability. Trees 27:485-496

Bunn AG, Hughes MK, Salzer MW (2011) Topographically modified tree-ring chronologies as a potential means to improve paleoclimate inference: a letter. Clim Change 105:627-634

Campelo F, Vieira J, Nabais C (2013) Tree-ring growth and intraannual density fluctuations of Pinus pinaster responses to climate: does size matter? Trees 27:763-772

Carrer M, von Arx G, Castagneri D, Petit G (2015) Distilling allometric and environmental information from time series of conduit size: the standardization issue and its relationship to tree hydraulic architecture. Tree Physiol 35:27-33

Chuine I, Beaubien EG (2001) Phenology is a major determinant of tree species range. Ecol Lett 4:500-510

Cleland EE, Chuine I, Menzel A, Mooney HA, Schwartz MD (2007) Shifting plant phenology in response to global change. Trends Ecol Evol 22:357-365

Cook BI, Smerdon JE, Seager R, Coats S (2014) Global warming and 21st century drying. Clim Dyn 43:2607-2627

Cook BI, Ault TR, Smerdon JE (2015) Unprecedented 21st century drought risk in the American Southwest and Central Plains. Sci Adv 1:e1400082 (7 pages)

Cuny HE, Rathgeber CBK, Frank DC, Fonti P, Fournier M (2014) Kinetics of tracheid development explain conifer tree-ring structure. New Phytol 203:1231-1241

D'Arrigo RD, Wilson RJS, Liepert B, Cherubini P (2008) On the 'divergence problem' in northern forests: a review of the tree-ring evidence and possible causes. Glob Planet Change 60:289-305

de Luis M, Novak K, Raventós J, Gričar J, Prislan P, Čufar K (2011) Climate factors promoting intra-annual density fluctuations in Aleppo pine (Pinus halepensis) from semiarid sites. Dendrochronologia 29:163-169

Denne MP (1988) Definition of latewood according to Mork (1928). IAWA Bull 10:59-62

Deslauriers A, Morin H (2005) Intra-annual tracheid production in balsam fir stems and the effect of meteorological variables. Trees 19:402-408

Deslauriers A, Morin H, Bégin Y (2003) Cellular phenology of annual ring formation of Abies balsamea in the Quebec boreal forest (Canada). Can J For Res 33:190-200

Deslauriers A, Rossi S, Anfodillo T, Saracino A (2008) Cambial phenology, wood formation and temperature thresholds in two contrasting years at high altitude in southern Italy. Tree Physiol 28:863-871

Deslauriers A, Rossi S, Turcotte A, Morin H, Krause C (2011) A three-step procedure in SAS to analyze the time series from automatic dendrometers. Dendrochronologia 29:151-161
DeSoto L, De la Cruz M, Fonti P (2011) Intra-annual patterns of tracheid size in the Mediterranean tree Juniperus thurifera as an indicator of seasonal water stress. Can J For Res 41:1280-1294

Dufour B, Morin H (2013) Climatic control of tracheid production of black spruce in dense mesic stands of eastern Canada. Tree Physiol 33:175-186

Ellison AM, Bank MS, Clinton BD, Colburn EA, Elliott K, Ford CR, Foster DR, Kloeppel BD, Knoepp JD, Lovett GM, Mohan J, Orwig DA, Rodenhouse NL, Sobczak WV, Stinson KA, Stone JK, Swan CM, Thompson J, Von Holle B, Webster JR (2005) Loss of foundation species: consequences for the structure and dynamics of forested ecosystems. Front Ecol Environ 3:479-486

Grabherr G, Gottfried M, Pauli H (1994) Climate effects on mountain plants. Nature 369:448

Gričar J, Zupancic M, Čufar K, Koch G, Schmitt U, Oven P (2006) Effect of local heating and cooling on cambial activity and cell differentiation in the stem of Norway spruce (Picea abies). Ann Bot 97:943-951

Gruber A, Strobl S, Veit B, Oberhuber W (2010) Impact of drought on the temporal dynamics of wood formation in Pinus sylvestris. Tree Physiol 30:490-501

Guay R (2013) WinCELL 2013 for wood cell analysis. Regent Instruments Canada Inc., Ontario

Gustafson EJ, Sturtevant BR (2013) Modeling forest mortality caused by drought stress: implications for climate change. Ecosystems 16:60-74

Harte J, Shaw R (1995) Shifting dominance within a montane vegetation community: results of a climate-warming experiment. Science 267:876-880

Hertzberg M, Aspeborg H, Schrader J, Andersson A, Erlandsson R, Blomqvist K, Bhalerao R, Uhlén M, Teeri TT, Lundeberg J, Sundberg B, Nilsson P, Sandberg G (2001) A transcriptional roadmap to wood formation. Proc Natl Acad Sci 98: 14732-14737

Johnson BG, Verburg PSJ, Arnone JA III (2014) Effects of climate and vegetation on soil nutrients and chemistry in the Great Basin studied along a latitudinal-elevational climate gradient. Plant Soil 382:151-163

Kahm M, Hasenbrink G, Lichtenberg-Fraté H, Ludwig J, Kschischo M (2010) grofit: fitting Biological growth curves with R. J Stat Softw 33:1-21

Kelly AE, Goulden ML (2008) Rapid shifts in plant distribution with recent climate change. Proc Nat Acad Sci 105:11823-11826

King GM, Gugerli F, Fonti P, Frank DC (2013) Tree growth response along an elevational gradient: climate or genetics? Oecologia 173:1587-1600

Körner C, Paulsen J (2004) A world-wide study of high altitude treeline temperatures. J Biogeogr 31:713-732

LaMarche VC Jr (1969) Environment in relation to age of bristlecone pines. Ecology 50:54-59

LaMarche VC Jr, Mooney HA (1972) Recent climatic change and development of the bristlecone pine ( $P$. longaeva Bailey) krummholz zone, Mt. Washington Nevada. Arct Alp Res $4: 61-72$

Le Houérou HN (1996) Climate change, drought and desertification. J Arid Environ 34:133-185

Lenz A, Hoch G, Körner C (2013) Early season temperature controls cambial activity and total tree ring width at the alpine treeline. Plant Ecol Divers 6:365-375

Letts MG, Nakonechny KN, Van Gaalen KE, Smith CM (2009) Physiological acclimation of Pinus flexilis to drought stress on contrasting slope aspects in Waterton Lakes National Park, Alberta, Canada. Can J For Res 39:629-641

Liang W, Heinrich I, Simard S, Helle G, Liñán ID, Heinken T (2013) Climate signals derived from cell anatomy of Scots pine in NE Germany. Tree Physiol 33:833-844 
Lupi C, Morin H, Deslauriers A, Rossi S (2010) Xylem phenology and wood production: resolving the chicken-or-egg dilemma. Plant Cell Environ 33:1721-1730

Lupi C, Rossi S, Vieira J, Morin H, Deslauriers A (2014) Assessment of xylem phenology: a first attempt to verify its accuracy and precision. Tree Physiol 34:87-93

Martin-Benito D, Beeckman H, Cañellas I (2013) Influence of drought on tree rings and tracheid features of Pinus nigra and Pinus sylvestris in a mesic Mediterranean forest. Eur J For Res 132:33-45

McCulloh KA, Sperry JS, Lachenbruch B, Meinzer FC, Reich PB, Voelker SL (2010) Moving water well: comparing hydraulic efficiency in twigs and trunks of coniferous, ring-porous, and diffuse-porous saplings from temperate and tropical forests. New Phytol 186:439-450

Mensing SA, Strachan S, Arnone JA III, Fenstermaker LF, Biondi F, Devitt DA, Johnson BG, Bird B, Fritzinger E (2013) A network for observing Great Basin climate change. Eos Trans Am Geophys Union 94:105-106

Menzel A, Fabian P (1999) Growing season extended in Europe. Nature 397:659

Moser L, Fonti P, Büntgen U, Franzen J, Esper J, Luterbacher J, Frank DC (2010) Timing and duration of European larch growing season along altitudinal gradients in the Swiss Alps. Tree Physiol 30:225-233

Nord EA, Lynch JP (2009) Plant phenology: a critical controller of soil resource acquisition. J Exp Bot 60:1927-1937

Oberhuber W, Gruber A, Kofler W, Swidrak I (2014) Radial stem growth in response to microclimate and soil moisture in a drought-prone mixed coniferous forest at an inner Alpine site. Eur J For Res 133:467-479

Olano JM, Eugenio M, García-Cervigón AI, Folch M, Rozas V (2012) Quantitative tracheid anatomy reveals a complex environmental control of wood structure in continental Mediterranean climate. Int J Plant Sci 173:137-149

Oribe Y, Kubo T (1997) Effect of heat on cambial reactivation during winter dormancy in evergreen and deciduous conifers. Tree Physiol 17:81-87

Panyushkina IP, Hughes MK, Vaganov EA, Munro MAR (2003) Summer temperature in northeastern Siberia since 1642 reconstructed from tracheid dimensions and cell numbers of Larix cajanderi. Can J For Res 33:1905-1914

Parmesan C, Yohe G (2003) A globally coherent fingerprint of climate change impacts across natural systems. Nature 421:37-42

Perry LG, Andersen DC, Reynolds LV, Nelson SM, Shafroth PB (2012) Vulnerability of riparian ecosystems to elevated CO2 and climate change in arid and semiarid western North America. Glob Change Biol 18:821-842

Pittermann J, Sperry J (2003) Tracheid diameter is the key trait determining the extent of freezing-induced embolism in conifers. Tree Physiol 23:907-914

$\mathrm{R}$ Core Team (2015) R: a language and environment for statistical computing. R Foundation for Statistical Computing, Vienna. ISBN 3-900051-07-0

Redmond KT, Koch RW (1991) Surface climate and streamflow variability in the western United States and their relationship to large-scale circulation indices. Water Resour Res 27:2381-2399

Richardson AD, Anderson RS, Arain MA, Barr AG, Bohrer G, Chen G, Chen JM, Ciais P, Davis KJ, Desai AR, Dietze MC, Dragoni D, Garrity SR, Gough CM, Grant R, Hollinger DY, Margolis HA, McCaughey H, Migliavacca M, Monson RK, Munger JW, Poulter B, Raczka BM, Ricciuto DM, Sahoo AK, Schaefer K, Tian H, Vargas R, Verbeeck H, Xiao J, Xue Y (2012) Terrestrial biosphere models need better representation of vegetation phenology: results from the North American Carbon Program Site Synthesis. Glob Change Biol 18:566-584
Rossi S, Deslauriers A, Morin H (2003) Application of the Gompertz equation for the study of xylem cell development. Dendrochronologia 21:33-39

Rossi S, Anfodillo T, Menardi R (2006a) Trephor: a new tool for sampling microcores from tree stems. IAWA J 27:89-97

Rossi S, Deslauriers A, Anfodillo T, Morin H, Saracino A, Motta R, Borghetti M (2006b) Conifers in cold environments synchronize maximum growth rate of tree-ring formation with day length. New Phytol 170:301-310

Rossi S, Deslauriers A, Anfodillo T, Carraro V (2007) Evidence of threshold temperatures for xylogenesis in conifers at high altitudes. Oecologia 152:1-12

Rossi S, Deslauriers A, Anfodillo T, Carrer M (2008) Age-dependent xylogenesis in timberline conifers. New Phytol 177:199-208

Rossi S, Morin H, Deslauriers A, Plourde P-Y (2011) Predicting xylem phenology in black spruce under climate warming. Glob Change Biol 17:614-625

Rossi S, Anfodillo T, Čufar K, Cuny HE, Deslauriers A, Fonti P, Frank DC, Gričar J, Gruber A, King GM, Krause C, Morin H, Oberhuber W, Prislan P, Rathgeber CBK (2013) A meta-analysis of cambium phenology and growth: linear and non-linear patterns in conifers of the northern hemisphere. Ann Bot 112:1911-1920

Rossi S, Girard M-J, Morin H (2014) Lengthening of the duration of xylogenesis engenders disproportionate increases in xylem production. Glob Change Biol 20:2261-2271

Rossi S, Cairo E, Krause C, Deslauriers A (2015) Growth and basic wood properties of black spruce along an alti-latitudinal gradient in Quebec, Canada. Ann For Sci 72:77-87

Rozas V, García-González I, Zas R (2011) Climatic control of intraannual wood density fluctuations of Pinus pinaster in NW Spain. Trees 25:443-453

Rundel PW, Yoder BJ (1998) Ecophysiology of Pinus. In: Richardson DM (ed) Ecology and Biogeography of Pinus. Cambridge University Press, New York, pp 296-323

Salzer MW, Larson ER, Bunn AG, Hughes MK (2014) Changing climate response in near-treeline bristlecone pine with elevation and aspect. Environ Res Lett 9:114007

Savidge R (2001) Intrinsic regulation of cambial growth. J Plant Growth Regul 20:52-77

Seo J-W, Eckstein D, Jalkanen R, Rickebusch S, Schmitt U (2008) Estimating the onset of cambial activity in Scots pine in northern Finland by means of the heat-sum approach. Tree Physiol 28:105-112

Sperry JS, Hacke UG, Pittermann J (2006) Size and function in conifer tracheids and angiosperm vessels. Am J Bot 93:1490-1500

Steppe K, Sterck F, Deslauriers A (2015) Diel growth dynamics in tree stems: linking anatomy and ecophysiology. Trends Plant Sci 20:335-343

Sthultz CM, Gehring CA, Whitham TG (2009) Deadly combination of genes and drought: increased mortality of herbivore-resistant trees in a foundation species. Glob Change Biol 15:1949-1961

Sturm M, Racine C, Tape K (2001) Climate change: increasing shrub abundance in the Arctic. Nature 411:546-547

Szymczak S, Hetzer T, Bräuning A, Joachimski MM, Leuschner H-H, Kuhlemann J (2014) Combining wood anatomy and stable isotope variations in a 600-year multi-parameter climate reconstruction from Corsican black pine. Quat Sci Rev 101:146-158

Takahashi K, Okuhara I (2013) Forecasting the effects of global warming on radial growth of subalpine trees at the upper and lower distribution limits in central Japan. Clim Change 117:273-287

Thomas CD, Cameron A, Green RE, Bakkenes M, Beaumont LJ, Collingham YC, Erasmus BFN, de Siqueira MF, Grainger A, Hannah L, Hughes L, Huntley B, van Jaarsveld AS, Midgley GF, Miles L, Ortega-Huerta MA, Peterson AT, Phillips OL, Williams SE (2004) Extinction risk from climate change. Nature 427:145-148 
Tinner W, Colombaroli D, Heiri O, Henne PD, Steinacher M, Untenecker J, Vescovi E, Allen JRM, Carraro G, Conedera M, Joos F, Lotter AF, Luterbacher J, Samartin S, Valsecchi V (2013) The past ecology of Abies alba provides new perspectives on future responses of silver fir forests to global warming. Ecol Monogr 83:419-439

Vaganov EA (1990) The tracheidogram method in tree-ring analysis and its application. In: Cook ER, Kairiukstis LA (eds) Methods of dendrochronology. Kluwer, Dordrecht, pp 63-76

Vaganov EA, Hughes MK, Shashkin AV (2006) Growth dynamics of conifer tree rings: images of past and future environments. Springer, New York

Vieira J, Rossi S, Campelo F, Freitas H, Nabais C (2013) Seasonal and daily cycles of stem radial variation of Pinus pinaster in a drought-prone environment. Agr For Meteorol 180:173-181

Vieira J, Rossi S, Campelo F, Freitas H, Nabais C (2014) Xylogenesis of Pinus pinaster under a Mediterranean climate. Ann For Sci 71:71-80

Vieira J, Campelo F, Rossi S, Carvalho A, Freitas H, Nabais C (2015) Adjustment capacity of maritime pine cambial activity in drought-prone environments. PLoS One 10:e0126223

Worth JRP, Williamson GJ, Sakaguchi S, Nevill PG, Jordan GJ (2014) Environmental niche modelling fails to predict Last
Glacial Maximum refugia: niche shifts, microrefugia or incorrect palaeoclimate estimates? Glob Ecol Biogeogr 23:1186-1197

Xia J, Niu S, Ciais P, Janssens IA, Chen J, Ammann C, Arain A, Blanken PD, Cescatti A, Bonal D, Buchmann N, Curtis PS, Chen S, Dong J, Flanagan LB, Frankenberg C, Georgiadis T, Gough CM, Hui D, Kiely G, Li J, Lund M, Magliulo V, Marcolla B, Merbold L, Montagnani L, Moors EJ, Olesen JE, Piao S, Raschi A, Roupsard O, Suyker AE, Urbaniak M, Vaccari FP, Varlagin A, Vesala T, Wilkinson M, Weng E, Wohlfahrt G, Yan L, Luo Y (2015) Joint control of terrestrial gross primary productivity by plant phenology and physiology. Proc Nat Acad Sci 112:2788-2793

Ziaco E, Biondi F, Rossi S, Deslauriers A (2014a) Climatic influences on wood anatomy and tree-ring features of Great Basin conifers at a new mountain observatory. Appl Plant Sci 2(10):1400054

Ziaco E, Biondi F, Rossi S, Deslauriers A (2014b) Intra-annual wood anatomical features of high-elevation conifers in the Great Basin, USA. Dendrochronologia 32:303-312

Ziaco E, Biondi F, Rossi S, Deslauriers A (2016) Environmental drivers of cambial phenology in Great Basin bristlecone pine. Tree Physiol. doi:10.1093/treephys/tpw006 